\title{
Plant-microbe Cross-talk in the Rhizosphere: Insight and Biotechnological Potential
}

\author{
Shyamalina Haldar and Sanghamitra Sengupta*
}

Department of Biochemistry, University of Calcutta, 35 Ballygunge Circular Road, Kolkata-700019, India

\begin{abstract}
Rhizosphere, the interface between soil and plant roots, is a chemically complex environment which supports the development and growth of diverse microbial communities. The composition of the rhizosphere microbiome is dynamic and controlled by multiple biotic and abiotic factors that include environmental parameters, physiochemical properties of the soil, biological activities of the plants and chemical signals from the plants and bacteria which inhabit the soil adherent to root-system. Recent advancement in molecular and microbiological techniques has unravelled the interactions among rhizosphere residents at different levels. In this review, we elaborate on various factors that determine plant-microbe and microbe-microbe interactions in the rhizosphere, with an emphasis on the impact of host genotype and developmental stages which together play pivotal role in shaping the nature and diversity of root exudations. We also discuss about the coherent functional groups of microorganisms that colonize rhizosphere and enhance plant growth and development by several direct and indirect mechanisms. Insights into the underlying structural principles of indigenous microbial population and the key determinants governing rhizosphere ecology will provide directions for developing techniques for profitable applicability of beneficial microorganisms in sustainable agriculture and nature restoration.
\end{abstract}

Keywords: Agriculture, ecology, microbe-microbe interaction, plant-microbe interaction, rhizosphere, root exudates.

\section{INTRODUCTION}

Rhizosphere, the soil adjacent to plant-roots, is a unique niche for microbial colonization. The term, rhizosphere, was first coined by Lorenz Hiltner [1]. It is a complex chemical matrix replete with diverse microbial species. Rhizosphere microbial community is recruited from the surrounding soil which acts as a microbial seed bank, while the plants determine which members of this bulk soil reservoir of microorganisms will flourish and thrive in the rhizosphere [2]. The present review is organized mainly into three sections. In the first section, we define rhizosphere effect and discuss the role of different factors such as plant genotype, plant age and environmental interferences that affect rhizodeposition processes. In the second section, we elaborate how the chemistry at the root-soil interface influences the microbial community with a highlight on plant-microbe and microbe-microbe interactions. Finally, few studies have been cited which exploit the mechanistic and ecological knowledge of rhizosphere into the programs linked to bio-based agriculture and economy.

\section{RHIZOSPHERE-EFFECT}

'Rhizosphere effect', a term coined by Starkey (1938), is defined by collective processes occurring at the root-soil

\footnotetext{
*Address correspondence to this author at the Department of Biochemistry, University of Calcutta, 35 Ballygunge Circular Road, Kolkata-700019, India; Tel: 91-33-24614712; Fax: 91-33-24614849;

E-mail: sanghamitrasg@yahoo.com
}

interface of a plant and includes root exudation, microbial activity, genetic exchange, nutrient transformation and gradient diffusion [3]. In living plants, organic carbon released by plant roots is decomposed to $\mathrm{CO}_{2}$ in a mechanism known as rhizosphere priming effect (RPE) [4]. Although the estimate of plant carbon economy is still controversial, approximately one-third to half of total assimilated carbon is allocated to below-ground, of which $15-25 \%$ is exuded from the roots into the soil to induce fast carbon-turnover in the rhizosphere [4]. Due to intensive carbon uptake by the roots, other nutrients in the rhizosphere are strongly limited [5]. In contrast, in a root-free soil, all the nutrients except carbon are unlimited [6]. The surplus of easily available carbon and strong nutrient limitation, together, make the rhizosphere milieu strongly different from that of the root-free zones. The increased microbial number and activity in the rhizosphere compared to those in bulk soil are mainly due to the release of organic carbon by the plant roots [7].

The substances released by plant roots are collectively termed as "rhizodeposits." These compounds include (i) water-soluble ions and low-molecular-mass compounds such as mono-saccharides, amino acids and organic acids which are lost passively along a concentration gradient, (ii) highmolecular-mass compounds such as carbohydrates, proteins and lipids which are actively transported along an electrochemical gradient, (iii) insoluble mucilage composed of polysaccharides and polygalacturonic acid, (iv) an array of secondary metabolites such as antimicrobial compounds, nematicides and flavonoids and (v) remnants of the dead and 
lysed root-cap and border cells [8-11]. Of these, sugars and amino acids are thought to be released in the greatest quantities.

\section{FACTORS AFFECTING ROOT-EXUDATION}

The quantity and composition of rhizodeposits are influenced by a variety of biotic and abiotic factors and vary in time and space with respect to the position on the root [12]. The host-dependent factors include genotype and age of the plant while the abiotic components include different environmental factors, grazing activities and anthropometric habits [13]. The wide quantitative and qualitative variation in root exudation of different plant species suggests that it is determined by plant genetic makeup. In a study with eight accessions of Arabidopsis thaliana, a unique combination of exudates was found to be secreted from the plants of different cultivars grown simultaneously under uniform conditions. This gave rise to genotype-specific rhizobacterial communities at six weeks post-germination [14]. The cultivar-specific variation in root exudation is mainly regulated by the root system architecture (RSA) [15]. The zone immediately behind the root tip is considered to be the major site of exudation although different sites have been recorded to be active in different plant species [16, 17]. Furthermore, different parts of the root system exude different compounds. For example, asparagine and threonine are exuded from meristem and root elongation zone; glutamic acid, valine, leucine and phenylalanine are secreted from root hair zone; while aspartic acid is exuded from the whole root [18]. Use of ${ }^{14} \mathrm{C}$ to identify the sites of exudation from wheat roots has shown that non-diffusible materials are released from both primary and lateral root tips and diffusible materials are released from the whole length of roots [19].

In general, apical meristem of plant roots is covered by root cap which sloughs off as the root tip wends its way through the soil. These sloughed-off cap cells, known as 'border cells,' play a significant role in determining the rhizosphere chemical environment [20]. Border cells produce polysaccharide mucilages accounting for $2-12 \%$ of the total rhizodeposition and $10 \%$ of total carbon released by roots. The number of border cells varies between plant species and this variability appears to be related to the organization of the root apical meristem (RAM) in monocotyledons and dicotyledons [21]. Border cells regulate microbial interaction by avoiding pathogens and favoring association with beneficial microbes. They also protect against heavy metal toxicity [22]. The root cap and hair cells are also involved in secretion of compounds. Root hairs are the extensions of single epidermal cells and comprise as much as $77 \%$ of the total root surface area of cultivated crops, developing a connection between the plant and the rhizosphere [23]. They play an important role in rhizosphere processes including uptake of water, nutrients and exudation of different compounds [24]. In addition to the root cap and hair cells, other cells are also involved in secretion. For example, citrate secretion from maize roots in response to aluminum toxicity predominantly involves cortex and stellar cells located $5 \mathrm{~cm}$ above the root cap [25].
Plant age vis-a-vis developmental stages plays a pivotal role in characterizing root-exudation pattern by its impact on RSA. Garcia et al. (2001) has shown that exudation is positively correlated with root growth [26]. Seedlings produce the lowest amounts of root exudates which gradually increases until flowering and decreases again at maturity [27]. Plant developmental windows seem to influence the chemistry of root-exudates as well. Secretion of phenolic compounds and defense-related proteins by Arabidopsis roots at flowering stage has been correlated with the age-related resistance of the plant [28]. Accumulation of pathogenesis-related1 (PR1) in the apoplast of tobacco plant during its transition to flowering stage in response to infection by Phytopthora parasitica and interaction of Xa-21 resistance gene product with the $X$. oryzae Ax21 effector molecule during the vegetative growth of rice in response to infection by Xanthomonas oryzae pv. oryzae are other well studied examples of developmentally regulated plant defense mechanisms against fungal pathogens [29, 30].

The environmental factors affecting root exudation include soil characteristics such as soil texture, $\mathrm{pH}$, and moisture content in addition to climate, temperature, light and humidity. High soil moisture leads to hypoxia which may cause an increased anaerobic respiration rate, accumulation of ethanol, lactic acid and alanine in the rhizosphere [31]. The presence or absence of particular minerals or toxic metals in the soil affects the composition of root-exudation. For example, citric, malic and oxalic acids are secreted to detoxify aluminum; secretion of phenolic compounds is increased in phosphorus deficient soils [32, 33]. Secretion of signaling molecules like flavanones and flavones is enhanced in nitrogen limiting conditions [34]. Mineral-deficiency enhances the production of elicitors that influence root-exudation. Potassium deficiency increases jasmonic acid mediated defense responses [35]. Lower temperatures and light reduce the secretion of root exudates. For example, the exudation of tannins and phenolic compounds in Vicia faba was greatly reduced at $4{ }^{\circ} \mathrm{C}$ [36]. The root exudation process follows diurnal rhythms [37]. Flavonoid content in the root exudates from Almus glutinosa (L.) is elevated under light conditions [38]. The presence of neighboring plant species and the rhizosphere microflora also affect the root exudation. Outcome of glucosinolates activation in Arabidopsis was regulated by the presence of neighboring plants. Production of glucosinolates is increased in a high-density environment having large number of Arabidopsis plants grown together compared with a lowdensity range [39].

\section{ROOT EXUDATES AND MICROBIAL COLONIZATION}

The structural and functional diversities of rhizosphere microbial communities of a wide variety of plants including Arabidopsis, Medicago, maize, pea, wheat and sugar beet are shaped by plant developmental stages. For example, rhizosphere microbial communities in early development of Arabidopsis were different from that observed in the bulk soil and this difference decreased with plant age [14]. In an elegant study by Chaparro et al (2013) a strong correlation has been documented between compounds released from the roots at different stages of plant development and the 
expression of microbial genes involved in metabolism of specific compounds [29]. Metatranscriptomic analysis of the rhizosphere microbiome of Arabidopsis thaliana (genotype Pna-10) revealed that eighty-one unique transcripts were significantly expressed at different stages of plant development. It was surmised from these studies that the blend of compounds and phytochemicals in the root-exudates were differentially produced at distinct stages of plant development and orchestrated the rhizobiota.

Components of root exudates are diverse and the researchers have only begun to dissect the role on individual compound. Carbohydrates, organic acids and amino acids stimulate positive chemotactic responses in bacteria [40]. The capacities of different microbial species to compete for these substrates and utilize vary. In the rhizosphere of maize, exudation of the benzoxazinone DIMBOA (2,4-dihydroxy-7methoxy-1,4-benzoxazin-3-one) resulted in an increase of population density of Pseudomonas putida strain with plant beneficial characteristics [41]. In A. thaliana, active exudation of phytochemicals mediated by ABC (ATPbinding cassette) transporters was demonstrated [42]. Phenolic compounds in the root exudates were suggested to send specific signals for soil bacteria [43]. Besides chemoattraction, root exudates regulate the adherence, colonization and formation of biofilm in the rhizosphere among the bacterial isolates [44]. Many soil-borne organisms follow the concentration gradients of sugars and amino acids towards the root. This leads to differential proliferation of microorganisms along different compartments of rhizosphere [44]. Since quantity and composition of root exudates respond rapidly to subtle environmental changes, the selective pressure exerted on microbial communities varies spatiotemporally [45]. Rhizosphere $\mathrm{pH}$ also shapes microbial ecology in the root environment [46]. Root-induced $\mathrm{pH}$ changes have a dramatic impact on key biogeochemical processes such as (i) dissolution/precipitation of soil minerals and (ii) adsorption/desorption of ions, and hence bioavailability of either anions (e.g. phosphate) or cations (e.g. copper). Further understanding of rhizosphere biogeochemistry is required to quantify the driving role of higher plants in ecosystem services such as soil formation and nutrient cycling.

\section{PLANT-MICROBE AND MICROBE-MICROBE INTERACTIONS}

The plant-microbe interaction in the rhizosphere may be categorized as associative, symbiotic, neutralistic, or parasitic. The positive interactions include symbiotic and associative interactions with beneficial microbes, such as endo- and ecto-mycorrhizal fungi, nitrogen-fixing bacteria and plant growth-promoting rhizobacteria (PGPR) whereas negative interactions include association with parasitic plants, pathogenic bacteria, fungi, oomycetes, nematodes and invertebrate herbivores.

Symbiosis between legume plants and Rhizobia in the soil is of particular importance in agriculture and much research has been focused on characterization of the molecular mechanisms that establishes species-specific collaboration [47]. Legume-Rhizobia interactions are mediated by host-specific flavonoids secreted in the rootexudates (Table 1). These molecules belong to a diverse

Table 1. List of compounds attracting Rhizobia from the root exudates of legumes.

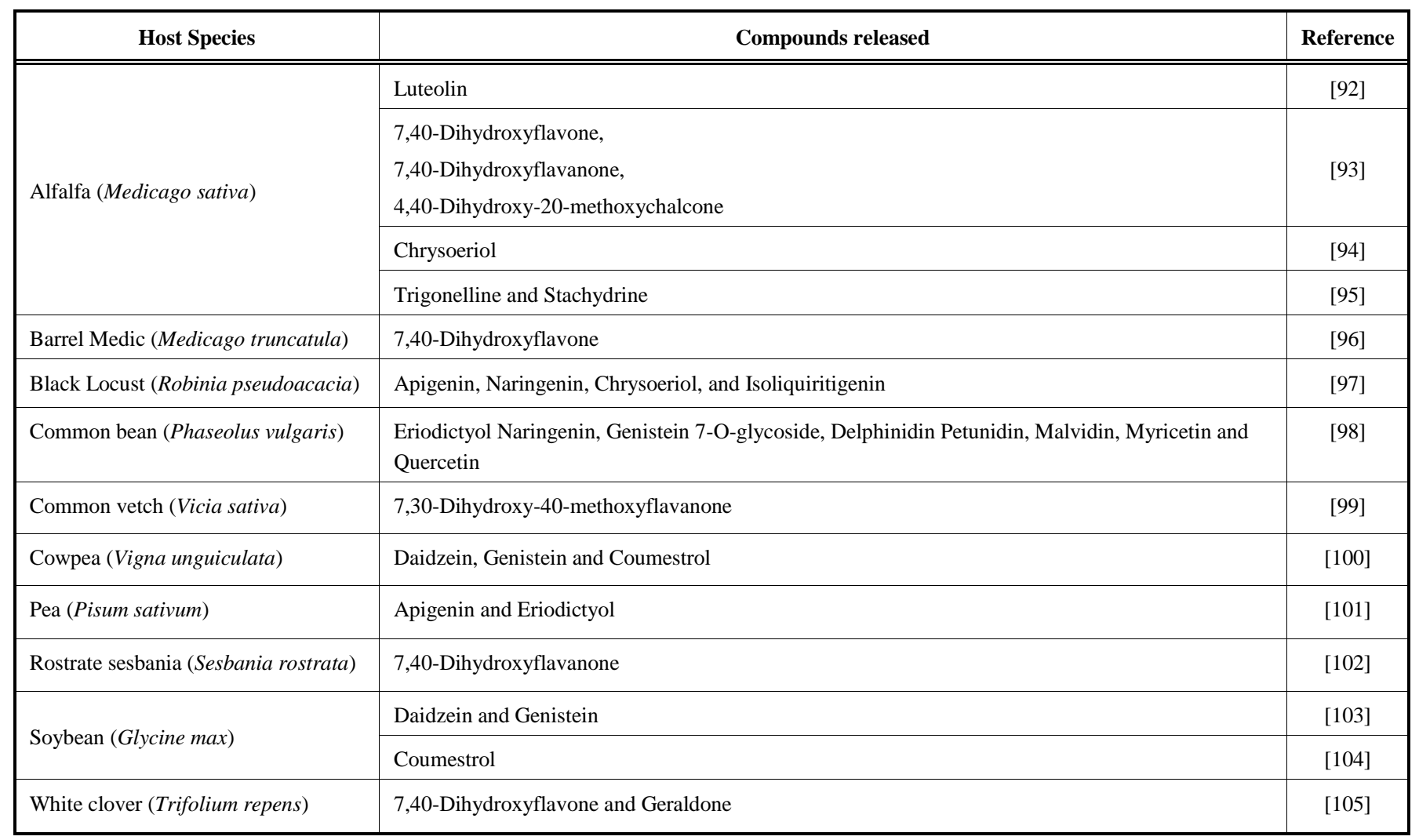


family of aromatic compounds derived from plant's secondary metabolism. Depending on the host and the bacterium, flavonoids activate a series of transcriptional events culminating in the production of main rhizobial nodulation signals called Nod factors (NF) or lipo-chito oligosaccharides (LCOs) [48]. Nod factors induce diverse developmental processes in the plant partner leading to morphological changes in legume root hairs, infection thread formation, nodule development and symbiotic nitrogen fixation [49]. Rhizobium sp. is a vast group of soil-borne rhizobia with other plant growth promoting activities such as siderophore production and disease suppression [50, 51].

The arbuscular mycorrhiza fungi (AMF) symbiotically interact with more than $80 \%$ of plant species [52]. AMF forms hyphal branching to establish it's contact with the roots and the "branching factor" at play has been recognized to be strigolactone [53]. Strigolactone is exuded from the roots and considered to be the plant signal molecule for AMF symbiosis [53]. The fragility of these compounds results in a steep concentration gradient which determines these obligate biotrophs to reach living plant roots. It is hypothesized that AMF may use the ancestral receptor to perceive signals of strigolactones in the rhizosphere [54]. Hence, the identification of the receptors for strigolactones in fungi might be a fascinating topic for future research.

Rhizosphere microbial populations are not simple spectators. They too communicate among themselves in addition to interacting with the plant root system. Based on their primary effects, the beneficial rhizosphere organisms are generally classified into two broad groups (i) biological control agents (BCA) that indirectly assist with plant productivity through the control of plant pathogens and (ii) plant growth promoting microorganisms (PGPM) with direct effects on plant growth promotion.

BCA adversely affect the population density, spatiotemporal dynamics and metabolic activities of soil borne pathogens via three types of interactions. These include competition, antagonism by producing secondary antimicrobial metabolites [55, 56], lytic enzymes [57] and effectors [58, 59] and hyperparasitism [60]. Trichoderma sp. is the most studied fungal BCA which has been proved to reduce plant diseases by multifarious modes of action. Bacillus amyloliquefaciens SQR9, isolated from cucumber rhizosphere, could protect the host from invasion by Fusarium oxysporum f.sp. cucumerinum J. H. Owen (FOC) through competition for nutrients and space [61]. Hyperparasitism among BCA involves the secretion of chitinases and cellulases which degrade pathogen's cell-wall [62]. This has been documented for Trichoderma [63, 64], Gliocladium [65] and Pasteuria penetrans [66]. The pathogens in the rhizosphere also exert diverse array of mechanisms to counteract antagonism. These include active efflux and degradation of antimicrobial compounds detoxification of oxygen radicals resulting from the oxidative stress generated by the antimicrobial compounds, conversion of antimicrobial metabolite into less toxic derivatives [67] and interference with the regulation and biosynthesis of enzymes and antimicrobial metabolites produced by antagonistic microorganisms [68]. BCAs have been shown to interfere with quorum sensing among plant pathogens as a mean to control plant diseases and promote plant health. Converse to quorum sensing, many pathogenic microorganisms execute "quorum quenching" by repression of the production or inactivation of quorum signaling molecules, or interference with the signal perception of rhizospheric colonizing bacteria $[69,70]$.

Studies on bacteria in the legume rhizosphere have shown that indigenous Rhizobia compete via either antagonism or synergism not only with diazotrophs such as Azotobacter and Azospirillum but with Pseudomonas and Bacillus species for nodulation and nitrogen fixation [71-73]. The diazotrophs manage important biological functions by symbiotically interacting with Rhizobium populations within the rhizosphere to form a beneficiary region where interacting microorganisms benefit from nutrient resources [72]. Synergistic effects of PGPR and Rhizobium enhance nodulation, rate of nitrogen fixation and better yield of crops such as pea, chickpea and pigeon pea [74, 75].

Beneficial effects of PGPR have been extensively exploited for economic gains in the recent years. PGPMs may act as biofertilizer [76] and/or phytostimulators [77]. The activity and effects of beneficial rhizosphere microorganisms on plant growth and health are well documented for bacteria belonging to the Proteobacteria noticeably Pseudomonas and Burkholderia, Firmicutes, Actinobacteria and fungi viz. Trichoderma, Gliocladium and nonpathogenic Fusarium oxysporum. Pseudomonads are common colonizers of plant tissues and traditionally known to be the major component of many rhizosphere communities. Pseudomonas sp. have been broadly studied for their ability to reduce the development of various soilborne plant pathogens through production of different antimicrobial compounds [78], competition for the nutrients in the root exudates [79] and induction of the plant defense mechanisms [80]. Multiple strains of fluorescent Pseudomonads viz. Pseudomonas fluorescence, Pseudomonas putida, Pseudomonas chloraphis were shown to improve plant growth in absence of pathogens by mechanisms such as directly solubilizing insoluble $\mathrm{P}$ sources [81] and/or regulating the concentration of plant growth regulators namely indole-acetic-acid or 1-amino-1-cycliccarboxylate (ACC) deaminase [82, 83]. Bacillus species offer several advantages over fluorescent Pseudomonads and other Gram-negative bacteria as seed inoculants by protecting against root pathogens by virtue of their ability to form endospores [84] and producing broad-spectrum antibiotics. There is a growing list of reports demonstrating rhizosphere colonization and root disease control by $B$. cereus UW85, B. megaterium B153-2-2 and B. subtilis GB03 which are involved in controlling damping-off in alfalfa and cotton and Rhizoctonia root-rot disease in soybean [85-87].

\section{TRANSLATING KNOWLEDGE INTO TECHNOLOGY}

Studies in rhizosphere research have undoubtedly improved our ability to steer the knowledge into 
technological applications in agriculture, ecological engineering and nature restoration. The applicability of PGPR in agriculture has been steadily increased as they offer the opportunity to replace chemical fertilizers, pesticides and mineral nutrients [88]. Cultivation of plant genotypes that can thrive on biotic and abiotic soil resources may also serve as an alternative in sustainable agriculture. This involves engineering plants with a higher level of resistance to pathogens via diverse mechanisms. For example, plants expressing bacterial acyl-homoserine lactonase and producing 5'-O-glucosyltransferase at an increased rate were shown to harbor enhanced resistance to plant pathogen, Pectobacterium carotovorum $[89,90]$. Recent studies on the rhizosphere ecology of non-cultivated plant species has increased an awareness of reconstructing soil structure by ecological engineering of soil biota. Rhizoremediation can provide a cost effective and environmentally sustainable "Green Technology" for the breakdown of petroleum contaminants from the soil. Carboxylates comprise a significant component of the root exudate mixture and it is hypothesized that these compounds may enhance biodegradation of petroleum hydrocarbons by promoting microbial activity by providing energy source. Future research involving the use of advanced techniques such as SIP combined with powerful metagenomic approaches will greatly improve our ability to understand microbialcarboxylate dynamics and aid in the improvement of rhizoremediation as a viable remediation strategy [91].

\section{CONCLUDING REMARKS}

This minireview aims to consolidate our current understanding of chemistry and biology of rhizosphere with regard to both host plant and the residing microbial community with an emphasis to appraise the role of root exudates in shaping rhizobiota. It also highlights the beneficial interactions between plants and different PGPM and BCA. This information, collectively, may serve as foundation for further research towards development of novel methods in sustainable agricultural practice. Despite the historical commitment and attention to the soil microbiome, its study has not kept pace with the recent surge of research activity as that of human microbiome. Plant microbiome is often termed as the second genome of plant and it is to be remembered that plant-microbe interaction is a "dialogue" rather than a unilateral relationship. Further investigation unraveling the 'specific' interactions in the rhizosphere will benefit the fundamental understanding of plant biology and provide stability of food production.

\section{CONFLICT OF INTEREST}

The authors declare that there is no conflict of interest.

\section{ACKNOWLEDGEMENTS}

SH was supported by the fellowship from Council of Scientific and Industrial Research, India (09/028(0751)/ 2008-EMR-I).

\section{REFERENCES}

[1] Hiltner L. U* ber neuere Erfahrungen und Probleme auf dem Gebiete der Bodenbakteriologie unterbessonderer Ber ucksichtigung der Gr"undung und Brache. Arb Dtsch Landwirtsch Ges Berl 1904; 98: 59-78.

[2] Lennon JT, Jones SE. Microbial seed banks: the ecological and evolutionary implications of dormancy. Nat Rev Microbiol 2011; 9: 119-30.

[3] Starkey RL. Some influences of the development of higher plants upon the microorganisms in the soil. VI. Microscopic examination of the rhizosphere. Soil Sci 1938; 45: 207-49.

[4] Kuzyakov Y. Review: Factors affecting rhizosphere priming effects. J Plant Nutr Soil Sci 2002; 165: 382-96.

[5] Breland TA, Bakken LR. Microbial growth and nitrogen immobilization in the root zone of barley (Hordeum vulgare L.), Italina rye grass (Lolium multiflorum, Lam.) and white clover (Trifolium repens, L.). Biol Fert Soils 1991; 12: 154-60.

[6] Wardle DA. A comparative assessment of factors which influence microbial biomass carbon and nitrogen levels in soil. Biol Rev 1992; 67: 321-58.

[7] Hartmann A, Schmid M, van Tuinen D, Berg G. Plant driven selection of microbes. Plant Soil 2009; 321: 235-57.

[8] Bowen GD, Rovira AD. The rhizosphere, the hidden half of the hidden half. In: Waisel Y, Eshel A, U Kafkafi, Eds: Plant Roots The Hidden Half. New York: Marcel Dekker, 1991; pp. 641-49.

[9] Hale MG, Moore LD, Griffin GJ. Root exudates and exudation. In: Elsevier Dommergues, YR, SV Krupa Eds: Interactions between non-pathogenic soil microorganisms and plants. Amsterdam: Elsevier, 1978 163-203.

[10] Marschner H. Mineral nutrition of higher plants. $2^{\text {nd }}$ ed. London: Academic Press 1995.

[11] Whipps JM. Carbon economy. In: Lynch JM, Ed. The rhizosphere. Chichester: John Wiley 1990; pp. 59-97.

[12] Darwent MJ, Paterson E, McDonald AJ, Tomos AD. Biosensor reporting of root exudation from Hordeum vulgare in relation to shoot nitrate concentration. J Exp Bot 2003; 54: 325-34.

[13] Philippot L, Raaijmakers JM, Lemanceau P, van der Putten WH. Going back to the roots: the microbial ecology of the rhizosphere. Nat Rev Microbiol 2013; 11: 789-99.

[14] Micallef SA, Channer S, Shiaris MP, Colon-Carmona A. Plant age and genotype impact the progression of bacterial community succession in the Arabidopsis rhizosphere. Plant Signal Behav 2009; 4: 777-80.

[15] Badri DV, Vivanco JM. Regulation and function of root exudates. Plant Cell Environ 2009; 32: 666-81.

[16] Schroth MN, Snyder WC. Exudation patterns from bean seeds and hypocotyls and their effects on Fusarium solanii $f$. phaseoliogy(Abstr.). Phytopathol 1962; 52: 751.

[17] Rovira AD. Plant root exudates. Bota Rev 1969; 35: 35-57.

[18] Frenzel B. Zur atiologie der anreicherung von aminosauren und amiden in wurzelraum von Helianthes annus. Ein Beitrag zur Klarung der Probleme der Rhizosphare. Planta 1960; 55: 169-207.

[19] McDougall BM, Rovira AD. Sites of exudation of 14Clabelled compounds from wheat roots. New Phytologist 1970; 69: 9991003 .

[20] Hawes MC. Living plant cells released from the root cap: a regulator of microbial populations in the rhizosphere. Plant Soil 1990; 129: 19-27.

[21] Sievers A, Braun M, Monshausen GB. The root cap: structure and function. In: Waisel Y, Eshel A, U Kafkafi, Eds. Plant root: The hidden half. $3^{\text {rd }}$ ed. New York: Marcel Dekker 2002; pp.33-47.

[22] Hawes MC, Gunawardena U, Miyasaka S, Zhao X. The role of root border cells in plant defense. Trends Plant Sci 2000; 5: 128-33.

[23] Parker JS, Cavell AC, Dolan L, Roberts K, Grierson CS. Genetic interactions during root hair morphogenesis in Arabidopsis. Plant Cell 2000; 12: 1961-74.

[24] Fan TW, Lane AN, Shenker M, Bartley JP, Crowley D, Higashi RM. Comprehensive chemical profiling of gramineous plant root exudates using high-resolution NMR and MS. Phytochemistry 2001; 57: 209-21.

[25] Pineros MA, Magalhaes JV, Carvalho Alves VM, Kochian LV. The physiology and biophysics of an aluminum tolerance mechanism based on root citrate exudation in maize. Plant Physiol 2002; 129: 1194-206.

[26] Garcia JAL, Barbas C, Probanza A, Barientos ML, Manero FJG. Low molecular weights organic acids and fatty acids in root exudates of two Lupinus cultivars at flowering and fruiting stages. Phytochem Anal 2001; 12: 305-11. 
[27] Aulakh MS, Wassmann R, Bueno C, Kreuzwieser J, Rennenberg H. Characterization of root exudates at different growth stages of ten rice (Oryza sativa L.) cultivars. Plant Biol 2001; 3: 139-48.

[28] De-la-Pena C, Badri DV, Lei Z, et al. Root secretion of defenserelated proteins is development-dependent and correlated with flowering time. J Biol Chem 2010; 285: 30654-65.

[29] Chaparro JM, Badri DV, Bakker MG, Sugiyama A, Manter DK, Vivanco JM. Root exudation of phytochemicals in Arabidopsis follows specific patterns that are developmentally programmed and correlate with soil microbial functions. PLoS One 2013; 8: e55731.

[30] Wilson DC, Carella P, Isaacs M, Cameron RK. The floral transition is not the developmental switch that confers competence for the Arabidopsis age-related resistance response to Pseudomonas syringae pv. tomato. Plant Mol Biol 2013 ; 83: 235-46.

[31] Rivoal J, Hanson AD. Metabolic control of anaerobic glycolysisoverexpression of lactate dehydrogenase in transgenic tomato roots supports the Davies-Roberts hypothesis and points to a critical role for lactate secretion. Plant Physiol 1994; 106: 1179-85.

[32] Wang C, Meek DJ, Panchal P, et al. Isolation of poly-3hydroxybutyrate metabolism genes from complex microbial communities by phenotypic complementation of bacterial mutants. Appl Environ Microbiol 2006; 72: 384-91.

[33] Neumann G, Romheld V. The release of root exudates as affected by the plant physiological status. In: Pinton R, Varanini Z, Nannipieri Z, Eds. The rhizosphere: biochemistry and organic substances at the soil-plant interfaced ed. New York: Marcel Dekker 2000; pp.41-93.

[34] Abdel-Lateif K, Bogusz D, Hocher V. The role of flavonoids in the establishment of plant roots endosymbioses with arbuscular mycorrhiza fungi, Rhizobia and Frankia bacteria. Plant Signal Behav 2012; 7: 636-41.

[35] Schachtman DP, Shin R. Nutrient sensing and signaling: NPKS. Annu Rev Plant Biol 2007; 58: 47-69.

[36] Bekkara F, Jay M, Viricel MR, Rome S. Distribution of phenolic compounds within seed and seedlings of two Vicia faba cvs differing in their see tannin content and study of their seed and root phenolic exudations. Plant Soil 1998; 203: 27-36.

[37] Watt M, Evans JR. Linking development and determinacy with organic acid efflux from proteoid roots of white lupin grown with low phosphorus and ambient or elevated atmospheric $\mathrm{CO}_{2}$ concentration. Plant Physiol 1999; 120: 705-16.

[38] Hughes M, Donnelly C, Crozier A, Wheeler CT. Effects of the exposure of roots Almus glutinosa to light on flavonoid and nodulation. Can J Bot 1999; 77: 1311-15.

[39] Wentzell AM, Kliebenstein DJ. Genotype, age, tissue, and environment regulate the structural outcome of glucosinolate activation. Plant Physiol 2008; 147: 415-28.

[40] Somers E, Vanderleyden J, Srinivasan M. Rhizosphere bacterial signalling: a love parade beneath our feet. Crit Rev Microbiol 2004; 30: 205-40.

[41] Neal AL, Ahmad S, Gordon-Weeks R, Ton J. Benzoxazinoids in root exudates of maize attract Pseudomonas putida to the rhizosphere. PLoS One 2012; 7: e35498.

[42] Badri DV, Chaparro JM, Manter DK, Martinoia E, Vivanco JM. Influence of ATP-binding cassette transporters in root exudation of phytoalexins, signals, and in disease resistance. Front Plant Sci 2012; 3: 149.

[43] Badri DV, Chaparro JM, Zhang R, Shen Q, Vivanco JM. Application of natural blends of phytochemicals derived from the root exudates of Arabidopsis to the soil reveal that phenolic-related compounds predominantly modulate the soil microbiome. J Biol Chem 2013; 288: 4502-12.

[44] Zhang N, Wang D, Liu Y, Li S, Shen Q, Zhang R. Effects of different plant root exudates and their organic acid components on chemotaxis, biofilm formation and colonization by beneficial rhizosphere-associated bacterial strains. Plant Soil 2014; 374: 689700 .

[45] Dilkes NB, Jones DL, Farrar J. Temporal dynamics of carbon partitioning and rhizodeposition in wheat. Plant Physiol 2004; 134: 706-15.

[46] Bravin MN, Tentscher P, Rose J, Hinsinger P. Rhizosphere $\mathrm{pH}$ gradient controls copper availability in a strongly acidic soil. Environ Sci Technol 2009; 43: 5686-91.

[47] Werner D. Molecular biology and ecology of the rhizobia-legume symbiosis. In: Pinton R, Varanini Z, Nannipiero P Eds. The rhizosphere: biochemistry and organic substances at the soil-plant interface. New York: CRC, 2007; 237-66.

[48] Spaink HP. Root nodulation and infection factors produced by rhizobial bacteria. Annu Rev Microbiol 2000; 54: 257-88

[49] D’Haeze W, Gao M, De Rycke R, Van Montagu M, Engler G, Holsters M. Roles for azorhizobial Nod factors and surface polysaccharide in intercellular invasion and nodule penetration respectively. Mol Plant Microbe Interact 1998; 11: 999-008.

[50] Huang HC, Erickson RS. Effect of seed treatment with Rhizobium leguminosarum on Pythium damping-of, seedling height, rot nodulation, rot biomas, shot biomas, and seed yield of pea and lentil. J Phytopathol 2007; 15: 31-7.

[51] Sidiqui ZA, Baghel G, Akhtar MS. Biocontrol of Meloidogyne javanica by Rhizobium and plant growth-promoting rhizobacteria on lentil. World J Microbiol Biotechnol 2007; 23: 435-41.

[52] Parniske M. Arbuscular mycorrhiza: the mother of plant root endosymbioses. Nat Rev Microbiol 2008; 6: 763-75.

[53] Akiyama K, Matsuzaki K, Hayashi H. Plant sesquiterpenes induce hyphal branching in arbuscular mycorrhizal fungi. Nature 2005; 435: 824-7.

[54] Parniske M. Plant-fungal associations: cue for the branching connection. Nature $2005 ; 435$ : 750-1.

[55] Raaijmakers JM, Vlami M, de Souza JT. Antibiotic production by bacterial biocontrol agents. Antonie van Leeuwenhoek 2002; 81: 537-47.

[56] Weller DM. Pseudomonas biocontrol agents of soilborne pathogens: looking back over 30 years. Phytopathology 2007; 97 . 250-6.

[57] Adesina MF, Lembke A, Costa R, Speksnijder A, Smalla K.Screening of bacterial isolates from various European soils for in vitro antagonistic activity towards Rhizoctonia solani and Fusarium oxysporum: site dependent composition and diversity revealed. Soil Biol Biochem 2007; 39: 2818-28.

[58] Stuber K, Frey J, Burnens AP, Kuhnert P. Detection of type III secretion genes as a general indicator of bacterial virulence. Mol Cell Probes 2003; 17: 25-32.

[59] Rezzonico F, Binder C, Defago G, Moenne-Loccoz Y. The type III secretion system of biocontrol Pseudomonas fluorescens KD targets the phytopathogenic Chromista Pythium ultimum and promotes cucumber protection. Mol Plant Microbe Interact 2005; 18: 991-1001.

[60] Harman GE, Howell CR, Viterbo A, Chet I, Lorito M. Trichoderma species--opportunistic, avirulent plant symbionts. Nat Rev Microbiol 2004; 2: 43-56.

[61] Liu Y, Zhang N, Qiu M, et al. Enhanced rhizosphere colonization of beneficial Bacillus amyloliquefaciens SQR9 by pathogen infection. FEMS Microbiol Lett 2014 ; 353: 49-56.

[62] Zeilinger S, Galhaup C, Payer K, et al. Chitinase gene expression during mycoparasitic interaction of Trichoderma harzianum with its host. Fungal Genet Biol 1999; 26: 131-40.

[63] Djonovic S, Pozo MJ, Kenerley CM. Tvbgn3, a beta-1,6-glucanase from the biocontrol fungus Trichoderma virens, is involved in mycoparasitism and control of Pythium ultimum. Appl Environ Microbiol 2006; 72: 7661-70.

[64] Woo SL, Scala F, Ruocco M, Lorito M. The molecular biology of the interactions between Trichoderma spp., phytopathogenic fungi, and plants. Phytopathology 2006; 96:181-85.

[65] Di Pietro A, Lorito M, Hayes CK, Broadway RM, Harman GE.Endochitinase from Gliocladium virens: isolation, characterization, and synergistic antifungal activity in combination with gliotoxin. Phytopathology 1993; 83: 308-13.

[66] Dupponois R, Ba AM, Mateille T. Beneficial effects of Enterobacter cloacae and Pseudomonas mendocina for biocontrol of Meloidogyne incognita with the endospore- forming bacterium Pasteuria penetrans. Nematology 1999; 1: 95-101.

[67] Schouten A, van den Berg G, Edel-Hermann V, et al. Defense responses of Fusarium oxysporum to 2,4-diacetylphloroglucinol, a broad-spectrum antibiotic produced by Pseudomonas fluorescens. Mol Plant Microbe Interact 2004; 17: 1201-11.

[68] Duffy B, Schouten A, Raaijmakers JM. Pathogen self-defense: mechanisms to counteract microbial antagonism. Annu Rev Phytopathol 2003;41: 501-38.

[69] Zhang LH, Dong YH. Quorum sensing and signal interference: diverse implications. Mol Microbiol 2004;53: 1563-71.

[70] Rasmussen TB, Givskov M. Quorum sensing inhibitors: a bargain of effects. Microbiology 2006; 152: 895-904. 
[71] Ahmad F, Ahmad I, Aqil F, Ahmed Wani A, Sousche YS. Plant growth promoting potential of free-living diazotrophs and other rhizobacteria isolated from Northern Indian soil. Biotechnol J 2006; 1: 1112-23.

[72] Gaind S, Rathi MS, Kaushik BD, Nain L, Verma OP. Survival of bio-inoculants on fungicides-treated seeds of wheat, pea and chickpea and subsequent effect on chickpea yield. J Environ Sci Health B 2007; 42: 663-68.

[73] Rodriguez A, Frioni L. Characterization of rhizobia causing nodules on leguminous trees native to Uruguay using the rep-PCR technique. Rev Argent Microbiol 2003; 35: 193-97.

[74] Halverson LJ, Handelsman J. Enhancement of soybean nodulation by Bacillus cereus UW85 in the field and in a growth chamber. Appl Environ Microbiol 1991; 57: 2767-70.

[75] Parmar N. Interactions of rhizosphere bacteria with CicerRhizobium symbiosis. Hisar, India: CCS Haryana Agricultural University 1995.

[76] Trabelsi D, Mhamdi R. Microbial inoculants and their impact on soil microbial communities: a review. Biomed Res Int 2013; 2013 863240 .

[77] Spaepen S, Vanderleyden J, Remans R. Indole-3-acetic acid in microbial and microorganism-plant signaling. FEMS Microbiol Rev 2007; 31: 425-48.

[78] Thrane C, Harder Nielsen T, Neiendam Nielsen M, Sorensen J, Olsson S. Viscosinamide-producing Pseudomonas fluorescens DR54 exerts a biocontrol effect on Pythium ultimum in sugar beet rhizosphere. FEMS Microbiol Ecol 2000; 33: 139-46.

[79] Pliego C, de Weert S, Lamers G, et al. Two similar enhanced rootcolonizing Pseudomonas strains differ largely in their colonization strategies of avocado roots and Rosellinia necatrix hyphae. Environ Microbiol 2008; 10: 3295-304.

[80] Mishra AK, Morang P, Deka M, Nishanth Kumar S, Dileep Kumar BS. Plant growth-promoting rhizobacterial strain-mediated induced systemic resistance in tea (Camellia sinensis (L.) O. Kuntze) through defense-related enzymes against brown root rot and charcoal stump rot. Appl Biochem Biotechnol 2014;174: 506-21.

[81] Naik PR, Raman G, Narayanan KB, Sakthivel N. Assessment of genetic and functional diversity of phosphate solubilizing fluorescent pseudomonads isolated from rhizospheric soil. BMC Microbiol 2008; 8: 230.

[82] Naik PR, Sahoo N, Goswami D, Ayyadurai N, Sakthivel N. Genetic and functional diversity among fluorescent pseudomonads isolated from the rhizosphere of banana. Microb Ecol 2008; 56: 492-504.

[83] Dey R, Pal KK, Bhatt DM, Chauhan SM. Growth promotion and yield enhancement of peanut (Arachis hypogaea L.) by application of plant growth-promoting rhizobacteria. Microbiol Res 2004; 159: 371-94.

[84] Kloepper JW, Ryu CM, Zhang S. Induced Systemic Resistance and Promotion of Plant Growth by Bacillus spp. Phytopathology 2004; 94: $1259-66$

[85] Halverson LJ, Clayton MK, Handelsman J. Variable stability of antibiotic-resistance markers in Bacillus cereus UW85 in the soybean rhizosphere in the field. Mol Ecol 1993; 2: 65-78.

[86] Handelsman J, Raffel S, Mester EH, Wunderlich L, Grau CR. Biological control of damping-off of alfalfa seedlings with Bacillus cereus UW85. Appl Environ Microbiol 1990; 56: 713-8.

[87] Senthilkumar M, Swarnalakshmi K, Govindasamy V, Lee YK, Annapurna K. Biocontrol potential of soybean bacterial endophytes against charcoal rot fungus, Rhizoctonia bataticola. Curr Microbiol 2009; 58: 288-93.
[88] Bhattacharyya PN, Jha DK. Plant growth-promoting rhizobacteria (PGPR): emergence in agriculture. World J Microbiol Biotechnol 2012; 28: 1327-50.

[89] Dong YH, Wang LH, Xu JL, Zhang HB, Zhang XF, Zhang LH. Quenching quorum-sensing-dependent bacterial infection by an Nacyl homoserine lactonase. Nature 2001; 411: 813-7.

[90] Lorenc-Kukula K, Jafra S, Oszmianski J, Szopa J. Ectopic expression of anthocyanin 5-o-glucosyltransferase in potato tuber causes increased resistance to bacteria. J Agric Food Chem 2005; 53: 272-81.

[91] Martin BC, George SJ, Price CA, Ryan MH, Tibbett M. The role of root exuded low molecular weight organic anions in facilitating petroleum hydrocarbon degradation: current knowledge and future directions. Sci Total Environ 2014; 472: 642-53.

[92] Peters NK, Frost JW, Long SR. A plant flavone, luteolin, induces expression of Rhizobium meliloti nodulation genes. Science 1986; 233: 977-80.

[93] Maxwell CA, Hartwig UA, Joseph CM, Phillips DA. A chalcone and Two Related Flavonoids Released from Alfalfa Roots Induce nod genes of Rhizobium meliloti. Plant Physiol 1989; 91: 842-7.

[94] Hartwig UA, Maxwell CA, Joseph CM, Phillips DA. Chrysoeriol and luteolin released from Alfalfa seeds induce nod genes in Rhizobium meliloti. Plant Physiol 1990; 92: 116-22.

[95] Phillips DA, Joseph CM, Maxwell CA. Trigonelline and stachydrine released from Alfalfa seeds activate NodD2 protein in Rhizobium meliloti. Plant Physiol 1992; 99:1526-31.

[96] Zhang J, Subramanian S, Zhang Y, Yu O. Flavone synthases from Medicago truncatula are flavanone-2-hydroxylases and are important for nodulation. Plant Physiol 2007; 144: 741-51.

[97] Scheidemann P, Wetzel A. Identification and characterization of flavonoids in the root exudate of Robinia pseudoacacia. Trees 1997; 11: 316-21.

[98] Hungria M, Joseph CM, Phillips DA. Anthocyanidins and flavonols, major nod gene inducers from seeds of a black-seeded common bean (Phaseolus vulgaris L.). Plant Physiol 1991; 97: $751-58$.

[99] Zaat SA, Schripsema J, Wijffelman CA, van Brussel AA, Lugtenberg BJ. Analysis of the major inducers of the Rhizobium nodA promoter from Vicia sativa root exudate and their activity with different nodD genes. Plant Mol Biol 1989; 13(2): 175-88.

[100] Dakora FD. Commonality of root nodulation signals and nitrogen assimilation in tropical grain legumes belonging to the tribe Phaseoleae. Aust J Plant Physiol 2000; 27: 885-92.

[101] Firmin JL, Wilson KE, Rossen L, Johnston AWB. Flavonoid activation of nodulation genes in Rhizobium reversed by other compounds present in plants. Nature 1986; 324: 90-2.

[102] Messens E, Geelen D, van Montagu M, Holsters M. 7,4Dihydroxyflavanone is the major Azorhizobium nod gene-inducing factor present in Sesbania rostrata seedling exudate. Mol PlantMicrobe Interact 1991; 4: 262-67.

[103] Kosslak RM, Bookland R, Barkei J, Paaren HE, Appelbaum ER. Induction of Bradyrhizobium japonicum common nod genes by isoflavones isolated from Glycine max. Proc Natl Acad Sci USA 1987; 84: 7428-32.

[104] Bassam BJ, Djordjevic MA, Redmond JW, Batley M, Rolfe BG. Identification of a nodD-dependent locus in the Rhizobium strain NGR234 activated by phenolic factors secreted by soybeans and other legumes. Mol Plant Microbe Interact 1988; 1: 161-8.

[105] Redmond J, Batley M, Djordjevic M, Innes R, Kuempel P, Rolfe B. Flavones induce expression of nodulation genes in Rhizobium. Nature 1986; 323: 632-5. 